\title{
Update on the challenges and recent advances in cancer immunotherapy
}

This article was published in the following Dove Press journal:

ImmunoTargets and Therapy

15 June 2013

Number of times this article has been viewed

\author{
Gianfranco Baronzio' \\ Gurdev Parmar ${ }^{2}$ \\ Irina ZH Shubina ${ }^{3}$ \\ Valter Cassutti' \\ Sergio Giuli' \\ Marco Ballerini' \\ Mikhail Kiselevsky ${ }^{3}$ \\ 'Centro Medico Demetra: \\ Hyperthermia and Immunity Center, \\ Terni, Italy; ${ }^{2}$ Integrated Health Clinic, \\ Fort Langley, British Columbia, \\ Canada; ${ }^{3}$ Blokhin Cancer Research \\ Center, Russian Academy of Medical \\ Sciences, Moscow, Russia
}

Correspondence: Gianfranco Baronzio Centro Medico Demetra: Hyperthermia and Immunity Center, via Cassian Bon, I/A 05100 Terni, Italy Tel +39 33I 877872

Email barongf@intercom.it

\begin{abstract}
This overview provides an analysis of some of the immunotherapies currently in use and under investigation, with a special focus on the tumor microenvironment, which we believe is a major factor responsible for the general failure of immunotherapy to date. It is our expectation that combining immunotherapy with methods of altering the tumor microenvironment and targeting regulatory $\mathrm{T}$ cells and myeloid cells will yield favorable results.
\end{abstract}

Keywords: tumor microenvironment, tumor immunity, immunosuppression, CTLA-4, PD-1, exosomes, myeloid-derived suppressor cells, $\mathrm{T}_{\text {regs }}$

\section{Introduction}

Metastasis occurs in the late stages of cancer development and partly represents the failure of both the innate and adaptive immune systems. ${ }^{1}$ Several factors support this process; among these, angiogenesis and chronic peritumoral inflammation may be two of the most important. ${ }^{1-3}$ There are also clinical factors that must be considered and may be of equal importance, such as tumor volume, ${ }^{4}$ prior treatment history, and the quality and quantity of that treatment, ${ }^{5,6}$ the struggle for nutrients, ${ }^{7}$ and the presence or absence of neurotransmitters. ${ }^{8}$ Despite this complexity, a clearer vision of the interactions between tumor and stroma/environment is possible, and its importance alongside immunotherapy is becoming more and more evident. ${ }^{9,10}$

Further, with the advent of new drugs (eg, ipilimumab), there has been a renewed clinical interest in cancer immunotherapy. Results from some of these newer immunologic drugs have suggested that active immunotherapy represents an important pathway to eliminating residual disease and obtaining durable and long-lasting responses in cancer patients. ${ }^{10,11}$

Within the tumor area, several cells are present at the same time. While some of these cells are normal residents, such as fibroblasts and cells of the immune system (leukocytes, lymphocytes, and macrophages), others are recruited. For example, several classes of cell types are recruited to the tumor environment specifically because of the hypoxic microenvironment. ${ }^{11-14}$ Resident cells initially try to continue their homeostatic existence controlling tumor growth but are eventually substituted by more immature cells - myeloid-derived suppressor cells (MDSCs) - recruited by bone marrow. ${ }^{13,14}$ Once MDSCs arrive into the tumor area, they are quickly differentiated into cells such as type 2 macrophages (M2s) ${ }^{14}$ or N2-type neutrophils, ${ }^{15}$ which are able to sustain this environment of angiogenesis and chronic inflammation. ${ }^{3,9}$ Ultimately, this results in the creation of an increasingly immunosuppressive environment,${ }^{16}$ with the invasion 
of MDSCs, ${ }^{16}$ regulatory $\mathrm{T}$ cells $\left(\mathrm{T}_{\text {regs }}\right),{ }^{17}$ Indoleamine 2, 3 -dioxygenase (IDO) cells, ${ }^{18}$ and exosomes, ${ }^{19}$ all of which present abundantly in the tumor microenvironment and merit comment as a supporting cast in this progression. ${ }^{9}$

\section{Cancer immunotherapy}

The importance of immunotherapy in cancer treatment and its relationship with other therapies is becoming increasingly better defined. This is certainly the case with chemotherapy, radiotherapy, and hyperthermia. The principal aim of these therapies is to kill tumor cells, which results in the elicitation of the tumor cells' antigens by way of presenting cells (dendritic cells [DCs] and macrophages). Thus, learning more about the effects of these treatments on the immune system is very important, and the effects are an important aspect of the interaction of these therapies with immune cells..$^{20-22}$ The development of recombinant interleukin (IL)- $2^{23}$ and of adoptive immunity against melanoma and renal cell carcinoma, by Rosenberg, ${ }^{24}$ has confirmed that immunity plays a fundamental role in tumor control and has opened a further therapeutic opportunity.

When the historical first attempts to use immunotherapy in the care of the cancer patient are discussed, mention must be made of Dr William Coley, the New York surgeon who developed what eventually became known as "Coley's toxins." ${ }^{25,26}$ These were used with a certain level of success, but the arrival of chemotherapy largely resulted in a universal abandonment of such therapies. However, as understanding of the role played by natural immunity and of toll-like receptors in cancer treatment has increased, ${ }^{27}$ the use of microbial treatments utilizing specific bacteria and oncolytic viruses has regained a certain importance. ${ }^{28,29}$ Further, with our ever-increasing knowledge of cancer immunity, it has become clear that cytotoxic lymphocytes (CTLs) and natural killer (NK) cells play a pivotal role in the cascade of antitumor immunity. We also know that the cytotoxic cellkilling function of these effectors of immune surveillance can be significantly enhanced by various modifying factors. Adoptive immunotherapy of cancer includes cytokines, particularly IL-2 and interferons $\alpha$ and $\gamma$, as well as ex vivo activated lymphocytes, the so-called lymphokine-activated killer (LAK) cells. In addition, recently, a promising biotherapy approach involving the design of tumor vaccines based on antigen-presenting DCs has been extensively developed. These two approaches have great potential, and biotherapy clinical trials of them are ongoing in the world's major cancer centers. ${ }^{24,30}$
The next part of this article briefly describes some aspects of adoptive immunotherapy and the modification of aspects of the tumor microenvironment, particularly $\mathrm{T}_{\text {regs }}$, exosomes, and MDSCs.

\section{Adoptive immunotherapy NKs}

NK cells were discovered in humans and mice in 1975, with specific functional criteria that correspond to their ability to lyse certain tumor cells in the absence of prior stimulation. NK cells are large granular lymphocytes that belong to the innate immune system. Unlike $\mathrm{T}$ or B lymphocytes of adaptive or antigen-specific immunity, NK cells do not rearrange T-cell receptor (TCR) or immunoglobulin genes from their germ-line configuration. ${ }^{31-37}$ Morphologically, NK cells are large granular lymphocytes that show (due to a large number of secreting granules) high functional activity. NK cells make up only $5 \%-20 \%$ of the total number of lymphocytes, ${ }^{34}$ including those that express cluster of differentiation (CD) 16 and CD56 surface markers. NK cells are able to detect and lyse cells despite deficiency in the expression of major histocompatibility complex (MHC) class I molecules, improving our understanding of the function and the role of NK cells in the immune response. ${ }^{36}$ NK cells have IL-2 receptors and can evidently be activated by this endogenous cytokine or its exogenous analogs. NK cells are thus effectors of innate immunity and, unlike T-killer cells, their function does not require a cascade of antigenpresentation reactions. ${ }^{37}$

As with neutrophils, NK cells may be considered the first line of defense of immune surveillance, as they can cause lysis of a transformed cell after contacting it, without any additional stimuli. However, their triggering function relies on a complex balance between inhibitory and activating signals that requires not only deficient MHC class I expression on target cells but also the expression of inducible ligands of activating NK-cell receptors. ${ }^{36,37}$ Both of these points are crucial for antitumor immunity performance, since, in the course of transformation, tumor cells may shed MHC molecules, lose tissue-specific antigens, and, what is more, can acquire features of embryonic cells (low-differentiated embryo carcinomas), thereby "escaping" specific immunity. However, these particular malignant cells may become the target for NKs, which have the ability to recognize and destroy a wide range of abnormal cells (including tumor, virus-infected, antibody-bound, and allogeneic cells) and stressed cells without damaging healthy and normal "self" cells. . $^{34,36,37}$ 


\section{LAK generation}

IL-2 stimulation of lymphocytes leads to expression of the so-called LAK cells. LAKs are a heterogeneous population of cells consisting primarily of NK, NKT, and T cells, which are generated in vitro by culture of peripheral blood mononuclear cells in the presence of IL-2. The major effector subset in the LAK population is of NK cells, which are mechanistically equivalent to peripheral blood NK cells but are more cytotoxic against tumor cells, including NK-resistant targets. ${ }^{38-41}$

\section{Adoptive IL-2/LAK therapy of cancer}

The first true clinical progress in immunotherapy was seen after the introduction of recombinant DNA technology for the production of immune-stimulating cytokines. Since 1985, studies on combined IL-2 and LAK cell treatment have been published. ${ }^{23,24}$ Such clinical trials have shown that high-dose IL-2 alone or in combination with LAK cells mediates objective tumor regression in $17 \%-28 \%$ of patients with metastatic renal cancer or metastatic melanoma, while prolonged remission was even observed in some patients with metastatic cancers. . $3,24,40^{2}$

Some authors have reported on clinical trials of the systemic treatment with high-dose IL-2 and tumor-infiltrating lymphocytes (autologous lymphocytes can be isolated from tumor-infiltrating cells, which presumably express tumorspecific TCRs) of patients with advanced cancer. Such treatment resulted in a $34 \%$ objective response rate of patients with metastatic melanoma. ${ }^{40}$ Although there was considerable clinical interest in LAKs for antitumor therapy by the end of the last century, LAK therapy has failed to obtain public support as a standard therapy for cancer patients. This was largely the result of limited responses to the immunotherapy when compared with those to chemotherapy or radiation therapy, and there were concerns about toxicity associated with the IL-2 infused simultaneously in order to maintain LAK activation. Another confounding factor was that most studies on immunotherapy used terminal-stage patients with virtually no remaining immune response capabilities, as they had failed to respond to previous conventional treatments. ${ }^{41}$

More recently, a new, cell-based immunotherapy utilizing activated lymphocytes has been suggested as an adjuvant regimen to radical surgery of cancer patients. Kimura and Yamaguchi ${ }^{42}$ conducted a randomized trial of 174 patients with non-small-cell lung carcinoma comparing IL-2/LAK therapy in combination with chemotherapy versus chemotherapy alone. Patients had undergone curative resection of their lung carcinoma and received six to eight courses of IL-2/LAK therapy over 2 years. The authors reported an improvement in the 5- and 9-year survival rates of $21 \%$ and $28 \%$, respectively.

Adjuvant treatment of solid tumors has also involved cytokine-induced killers (CIKs). CIK cells are a heterogeneous subset of ex vivo expanded T lymphocytes presenting a mixed T-NK phenotype and have unrestricted MHC antitumor activity. ${ }^{43}$ In the setting of hepatocellular carcinoma and gastric cancers, adjuvant infusions of autologous CIK cells after surgical resection resulted in a significant increase in disease-free survival. ${ }^{44-46}$ To increase IL-2/ LAK immunotherapy effectiveness, local and loco-regional infusions were performed, allowing for the effective concentration of activated killers at the site of the lesion. The most significant clinical effects were achieved with intra-cavity infusions of IL-2 and LAKs in patients with malignant effusions (pleuritis, ascites, and pericarditis). Malignant effusion regression was seen in 70\%-95\% of cases, showing good tolerance and effectiveness in chemotherapy-resistant cancer types. ${ }^{47}$ One of the advantages of adjuvant loco-regional immunotherapy is that these low IL-2 immunostimulating doses cause no marked side effects, including immune- and/or myelosuppression, which are characteristic of high-dose cytokine therapy.

These LAK- and CIK-cell immunotherapy methods aim to stimulate the innate chain of antitumor immunity, which is a reasonable approach because most tumors express little to no MHC or tumor antigens. It is also necessary to consider the fact that $\mathrm{T}$ killers constitute an essential part of lymphoid cell populations and are responsible for a more specific mechanism of action - in these conditions, they are not involved in the antitumor defense function. Therefore, another promising approach in antitumor biotherapy is focusing on designing vaccines, in particular DC-based vaccines, to activate adaptive immunotherapy.

\section{Tumor-infiltrating lymphocytes (TILs) in cancer immunotherapy}

TILs derived from patients with a variety of histological cancer types have demonstrated that cellular immune reactions against established malignancies exist in humans. TILs are heterogeneous populations of $\mathrm{T}$ cells, which contain not only CD4+ and CD8+ T lymphocytes (as previously reported), ${ }^{30,38,40}$ but also a small and, in some cases, significant fraction of $\gamma \delta \mathrm{T}$ cells, with a prevalence of the $\mathrm{V} \delta 1$ subset. ${ }^{48,49}$ 
TILs that infiltrate melanoma could specifically recognize tumor-associated antigens. ${ }^{30}$ Chemotherapyinduced lymphodepletion prior to adoptive cell infusion may lead to the dramatic enhancement of the persistence of the transferred cells and improved anticancer effects. ${ }^{30}$ Early results in patients with metastatic melanoma treated with the adoptive transfer of autologous TILs selected for antitumor activity - expanded in vitro and then re-infused into patients along with IL-2, following a lymphodepleting preparative regimen - do exist. ${ }^{30}$ In clinical trials with increasing lymphodepletion prior to infusion of autologous TILs, objective response rates between $49 \%$ and $72 \%$ were seen for patients with metastatic melanoma. ${ }^{30}$

Limitations of TIL therapy, including the requirement for surgery to isolate the tumor and the need to consistently generate $\mathrm{T}$ cells with antitumor activity, have led to novel strategies for redirecting normal $\mathrm{T}$ cells to recognize tumorassociated antigens (eg, NY-ESO-1, carcinoembryonic antigen [CEA], anti-CD20) using genetically engineered tumor antigen-specific TCRs or chimeric antigen receptor genes. As an alternative to TIL therapy, highly avid TCRs can be cloned from naturally occurring $\mathrm{T}$ cells, and then gene transfer vectors can be used to introduce these into the patient's lymphocytes. In this manner, large numbers of antigen-specific $\mathrm{T}$ cells can be rapidly generated, in comparison with the long-term expansion required for TILs. These highly reactive T-cell clones are able to recognize and effectively lyse target tumor cells..$^{30,48}$

Recently, several clinical trials have reported the clinical efficacy and benefit of gene-modified $\mathrm{T}$ cells for the treatment of different cancers, including melanoma, colorectal and synovial cell cancers, neuroblastoma, and lymphoma. In patients with synovial cell cancer, the measurable response rate was $66 \%$, while in melanoma patients this was $45 \% .{ }^{47,50}$

\section{Autologic vaccines based on DCs}

DCs are the quintessential antigen-presenting cells (APC) and have the unique ability to induce a primary immune response. DCs both prime naive cytotoxic T cells and activate long-term memory cells. In addition to these essential functions in adaptive immunity, DCs can also activate B cells and NKs. ${ }^{51}$

\section{Methods of DC generation to produce antitumor vaccines}

Mature DCs for antitumor vaccines are typically generated from CD14+ monocytes according to a well-known twostage method. The initial stage is cultivation for 6-7 days in the presence of granulocyte macrophage colony-stimulating factor and IL-4 in macrophage-conditioned medium. ${ }^{52}$

The second stage - DC maturation - may proceed in the presence of various factors, such as bacteria (live or dead), bacterial products, lipopolysaccharide, viruses, two-strand RNA or its analog poly-I:C, pro-inflammatory factors and their combinations (IL-1 $\beta$, tumor necrosis factor- $\alpha$, IL-6, prostaglandin E2 [PGE 2$]$ ), and CD40 ligand (CD40L). Compared to mature Dendritic Cells , maturing DCs lose their ability for endocytosis and the processing of antigens..$^{51,52}$

Early studies on the use of DCs involved only small groups of patients but reported potentially promising results. ${ }^{53,54}$ Today, we have access to the results of over 200 clinical trials that have assessed DC-based vaccines, yet their clinical effectiveness and expedience for use in cancer patients becomes more and more doubtful. Rosenberg et al argued that early optimism for DC vaccines was based on dubious surrogate end-points, which lacked robustness, rather than on proof of antitumor effects. ${ }^{55-57}$ One trial, conducted at the Surgery Branch of the National Cancer Institute on 440 patients, yielded an overall objective response rate of only $2.6 \%{ }^{55}$ This was comparable to the $4.0 \%$ response rate reported in 40 other smaller studies on a combined total of 756 patients. ${ }^{57}$ More recent studies have shown partial or complete regression rates of $4 \%-12 \%$ in patients with advanced cancer. ${ }^{55,57}$

When compared with IL-2/LAK therapy, the clinical effectiveness of DC-based therapy has not been reported to be more effective, and was sometimes less, than that of IL-2/LAK. ${ }^{55,57}$ These limited response rates may be due to the fact that DC-vaccine therapy results in stimulation of effector cells of innate immunity, where the antitumor effect is not specifically taught to $\mathrm{T}$ lymphocytes for long-lasting protection. Moreover, there are even data that suggest DC vaccination can have a detrimental effect and may even be associated with a worse outcome. ${ }^{57}$

In recent years, there have been reports about the efficiency of a new cell-based immunotherapy for advanced prostate cancer called "sipuleucel-T." Sipuleucel-T is an autologous active cellular immunotherapy consisting of peripheral blood mononuclear cells, including APCs. It is the first therapeutic cancer vaccine to have received US Food and Drug Administration approval. The treatment resulted in a prolonged median overall survival, but only in patients with no signs of disease progression. ${ }^{58-60}$ It is hypothesized that the activated APCs promote endogenous T cells to destroy prostatic acid phosphatase (PAP)-bearing prostate cancer cells, although the vaccine's precise mechanism of 
action is not yet understood. ${ }^{58-60}$ However, there is a lack of data about the generation of adaptive immunity using this method, suggesting that its antitumor effect is achieved mainly by activating effectors of innate immunity as a result of stimulating factors secreted by DCs; that is to say, the DCs may be considered a cellular adjuvant to NK cells and other innate immunity cells.

Overall, DC-based vaccines have not demonstrated any significant clinical efficacy and the outcomes of clinical trials have largely been poor. A more efficient approach using this method might be to use it to prolong progression-free survival in cancer patients who have had maximal cytoreduction via surgery and/or chemotherapy. ${ }^{61}$ DCs may also be used as a cellular adjuvant for other cancer immunotherapy strategies, in particular, in combination with LAK (CIK) therapy. ${ }^{62,63}$ Such an approach may improve the effectiveness of cellbased antitumor immunotherapy due to the simultaneous activation of both innate and adaptive immunity. Further, taking into account NK/DC interactions, such combination treatments may increase the effectiveness of LAK cells by DC stimulation and enhance the generation of CTLs in their presence.

\section{Control of the tumor microenvironment}

The tumor microenvironment is a microcosm of cells and extracellular matrices that continuously interact and evolve. The support cells (ie, fibroblasts, adipocytes), the matrix, and the immunity cells that are partly comprised of normal residents and partly of recruited cells ( $\mathrm{T}_{\text {regs }}$, MDSCs, macrophages, and neutrophils) work in concert with the tumor cells to create an inflammatory microenvironment that permits their growth and metastasis. ${ }^{11-13}$ The inflammatory microenvironment is largely responsible for the failure of host immune surveillance. ${ }^{64}$ Further, the excessive production of lipid mediators such as $\mathrm{PGE}_{2}$, immune regulator cytokines such as IL-10, and transforming growth factor- $\beta$ (TGF- $\beta$ ) carries through to immunosuppression. ${ }^{65,66}$ The excessive production of these lipid mediators in this already inflamed microenvironment allows for control of $\mathrm{T}_{\text {regs }}$ and MDSCs, ${ }^{65-67}$ creating the perfect conditions for chronic disease. ${ }^{65}$ The immunosuppressive activity of $\mathrm{PGE}_{2}$ has long been known, and we know it is continually produced by tumor cells and by their stroma. ${ }^{68}$ Its excessive production can regulate $\mathrm{T}_{\text {reg }}$ and MDSC recruitment. ${ }^{65-70}$ Cyclooxygenase-2 (COX2) inhibitors have been demonstrated to decrease $\mathrm{PGE}_{2}$, and thus the recruitment of $\mathrm{T}_{\text {regs }}$ in mouse mammary models ${ }^{71}$ and lung models, ${ }^{72}$ and are associated with a differentiation effect on
$\operatorname{MDSCs} s^{70,73}$ that has been demonstrated in rare tumors such as mesothelioma. ${ }^{74}$

Leibovici et $\mathrm{al}^{11,12}$ have noted that the tumor microenvironment is a target for TGF- $\beta$ action that stimulates tumor progression via pro-tumorigenic effects on vascular, immune, and fibroblastic cells. According to these authors, ${ }^{11,12}$ there are several preclinical types of TGF- $\beta$ inhibitors, each of which must be used prudently. Another approach to controlling the excessive production of TGF- $\beta$ in the tumor microenvironment is the use of oral proteolytic enzymes, as demonstrated by Desser et $\mathrm{al}^{75}$ in patients with rheumatoid arthritis, osteomyelofibrosis, and herpes zoster. The mechanism of action of these enzymes seems to be linked to inactivation by $\alpha 2$ macroglobulin. ${ }^{75}$ MDSCs are identified as $\mathrm{CD} 11 \mathrm{~b}+\mathrm{Gr} 1+$ in mice and CD33+HLA-DR-Lin-in humans although numerous additional markers (eg S100A, etc) have been used to categorize MDSC subsets. ${ }^{13,76-78}$ MDSCs are a heterogeneous group of mature and immature myeloid cells ${ }^{79}$ that demonstrate strong immunosuppressive activity, due to several factors triggered by the phosphorylation of signal transducer and activator of transcription 3 (STAT3). ${ }^{80}$ Once STAT3 is phosphorylated, MDSCs are activated and produce various products such as $\mathrm{PGE}_{2}$, vascular endothelial growth factor, reactive oxygen species, IL-10 and IL-6, nitric oxide synthase, and low-molecular-weight cytoplasmic proteins called S100A8/9 (which is able to fix calcium). ${ }^{80,81}$ Due to their heterogeneity, MDSCs are not easily treated; nonetheless, currently, several clinical approaches are in development and trials are underway to this end..$^{13,81-83}$ Various approaches have been used to attempt to control the recruitment, ${ }^{82}$ differentiation, ${ }^{13,81}$ and number - by appropriate chemotherapy - of MDSCs. ${ }^{84}$ Recently, Ghiringhelli et al reported on a novel approach to controlling tumor immunity and inflammation via polyphenols such as resveratrol, curcumin, genistein, and epigallocatechin. ${ }^{85}$ This novel treatment method is of particular interest at least because the side effects are minimal, and these natural molecules act simultaneously on a number of key control points (IL-10, TGF- $\beta$, PGE $_{2}$, leukotrienes) and by increasing tumor cell death. ${ }^{85}$ Some of the drugs used to modulate MDSCs in humans and their mechanisms of action are presented in Table $1^{13,17,70-92}$ and Figure 1.

Another group of cells present in the blood and the hypoxic tumor microenvironment that are able to suppress the host immune response $\mathrm{e}^{93,94}$ is the $\mathrm{T}_{\text {regs }}$, classified as CD4+CD25+FOxp3. They contribute to angiogenesis and to poor survival in many solid tumors such as ovary, breast, colorectal, lung, and pancreatic cancers. ${ }^{93-95} \mathrm{~T}_{\text {regs }}$ can be depleted or modulated in five ways: (1) by depletion (gemcitabine, ${ }^{93}$ 
Table I Clinical drugs modulating human myeloid-derived suppressor cells (MDSCs) and regulatory $T_{\text {cells }}\left(T_{\text {regs }}\right)$ and their mechanism(s) of action

\begin{tabular}{|c|c|c|c|c|}
\hline Drug(s) & Cancer & Mechanism(s) of action & PMA & Reference(s) \\
\hline Vitamin D3 & Head and neck & $\downarrow \mathrm{CD} 34(+), \uparrow \mathrm{CD} 8(+) \mathrm{T}$ cells & $\mathrm{D}$ & Lathers et $\mathrm{al}^{88} \mathrm{Ugel}_{\text {et }} \mathrm{a}^{92}$ \\
\hline ATRA & Renal carcinoma & $\begin{array}{l}\text { Induction of differentiation } \\
\downarrow \text { ROS }\end{array}$ & $\mathrm{D}$ & $\begin{array}{l}\text { Mirza et al }{ }^{89} \text { Apetoh et al, }{ }^{90} \\
\text { Ugel et al }\end{array}$ \\
\hline Sunitinib & Renal cell carcinoma & $\begin{array}{l}\text { Prevention of MDSC generation, } \\
\text { differentiation mediated by c-kit and } \\
\text { transcription factor (STAT3) inhibition }\end{array}$ & M & $\begin{array}{l}\text { Greten et al, }{ }^{79} \mathrm{Kao} \text { et al, }{ }^{82} \mathrm{Ko} \text { et al, }{ }^{86} \\
\text { Apetoh et al, }{ }^{90} \text { Ugel et al }{ }^{92}\end{array}$ \\
\hline COX2 inhibitors & Mesothelioma & $\downarrow$ recruitment of MDSCs & M & Veltman et $\mathrm{al}^{74}{ }^{74}$ Ugel et $\mathrm{al}^{92}$ \\
\hline $\begin{array}{l}\text { Bevacizumab } \\
\text { (anti-VEGF antibody) }\end{array}$ & $\begin{array}{l}\text { Metastatic renal, cervical, } \\
\text { colon, mesothelioma }\end{array}$ & $\begin{array}{l}\text { Induction of differentiation toward more } \\
\text { mature form of MDSCs }\end{array}$ & M & $\begin{array}{l}\text { Nagaraj and Gabrilovich, } \\
\text { van Cruijsen et al, }{ }^{91} \text { Ugel et al }{ }^{92}\end{array}$ \\
\hline Bisphosphonates & & $\downarrow$ number of MDSCs inside tumor stroma & M & Ugel et $\mathrm{a}^{92}$ \\
\hline Triterpenoids & & $\downarrow$ IF of MDSCs & $\mathrm{F}$ & Apetoh et al ${ }^{90}$ \\
\hline $\begin{array}{l}\text { Phosphodiesterase- } 5 \\
\text { inhibitors }\end{array}$ & $\begin{array}{l}\text { Head and neck cancer, } \\
\text { myeloma }\end{array}$ & $\downarrow$ arginine and NOS expression & $\mathrm{F}$ & $\begin{array}{l}\text { Apetoh et al, }{ }^{90} \text { Ugel et al, }{ }^{92} \\
\text { Nagaraj and Gabrilovich }{ }^{78}\end{array}$ \\
\hline COX2 inhibitors & & $\begin{array}{l}\text { Downregulation of arginine and NOS } \\
\text { expression of MDSCs }\end{array}$ & $\mathrm{F}$ & Ugel et al $\left.\right|^{92}$ \\
\hline Docetaxel & & Polarization of MDSCs toward MI & $\mathrm{F}$ & Apetoh et $\mathrm{al}^{90}$ \\
\hline Bindarit & & $\begin{array}{l}\downarrow \mathrm{CCL} 2 \text { production, } \rightarrow \downarrow \text { recruitment } \\
\text { of MDSCs }\end{array}$ & $A$ & Sevko and Umansky ${ }^{70}$ \\
\hline $5-\mathrm{FU}$ & & $\begin{array}{l}\uparrow \text { depletion of MDSCs, } \uparrow \text { cell death through } \\
\text { inhibition of thymidylate synthase }\end{array}$ & A & Apetoh et al, ${ }^{90}$ Ugel et $\mathrm{al}^{92}$ \\
\hline Gemcitabine & Pancreatic & $\begin{array}{l}\downarrow \text { number of MDSCs, } \uparrow \text { (elimination and } \\
\text { apoptosis) direct cytotoxicity }\end{array}$ & $A$ & Martin et al, ${ }^{13}$ Apetoh et $\mathrm{al}^{90}$ \\
\hline *Ipilimumab (CTLA-4) & Melanoma, prostate & $\downarrow$ number of $T_{\text {regs }}, \downarrow$ IF of $T_{\text {regs }}$ & & $\begin{array}{l}\text { Graziani et al, }{ }^{99} \text { Singh et al, }{ }^{105} \\
\text { Hodi et al }{ }^{106}\end{array}$ \\
\hline Tremelimumab & Melanoma & $\downarrow$ number of $T_{\text {regs }}$ & & Reuben et al ${ }^{115, * *}$ \\
\hline Cyclophosphamide & & $\downarrow$ number of $\mathrm{T}_{\text {regs }}, \downarrow$ IF of $\mathrm{T}_{\text {regs }}$ & & Tongu et al, ${ }^{87} \mathrm{Zou}^{95}$ \\
\hline COX2 inhibitors & Breast, lung & $\downarrow \mathrm{IF}, \downarrow$ recruitment of $\mathrm{T}_{\text {regs }}$ & & Karavitis et al, ${ }^{71}$ Sharma et al ${ }^{72}$ \\
\hline Denileukin diftitox & & $\begin{array}{l}\downarrow \text { number of } T_{\text {regs }} \text { through inhibition of } \\
\text { protein synthesis and } \uparrow \text { apoptosis }\end{array}$ & & Pere et al ${ }^{100}$ \\
\hline *PD-I & Melanoma, renal cell & $\downarrow$ function of $T_{\text {regs }}$ & & $\begin{array}{l}\text { Zitovgel and Kroemer, }{ }^{118} \text { Ménétrier- } \\
\text { Caux et al, }{ }^{119} \text { Topalian et al }{ }^{120}\end{array}$ \\
\hline $\begin{array}{l}\text { Daclizumab/basiliximab } \\
\text { (anti-CD25 mAbs) }\end{array}$ & Metastatic breast & $\downarrow$ of circulating $T_{\text {regs }}$ & & Ménétrier-Caux et al ${ }^{119}$ \\
\hline
\end{tabular}

Notes: *PD-I is better tolerated than CTLA-4; **clinically ineffective.

Abbreviations: 5-FU, fluorouracil; A, accumulation; ATRA, all-trans retinoic acid; CCL2, chemokine (C-C motif) ligand 2; CD, cluster of differentiation; COX2, cyclooxygenase-2; CTLA-4, cytotoxic T-lymphocyte antigen 4; D, differentiation; F, function; IF, immunosuppressive function; M, maturation; MI, type I macrophage; mAbs, monoclonal antibodies; NOS, nitric oxide synthase; PD-I, programmed cell death protein I; PMA, principal mechanism of action; ROS, reactive oxygen species; STAT3, signal transducer and activator of transcription 3; VEGF, vascular endothelial growth factor.

metronomic cyclophosphamide, ${ }^{96}$ denileukin diftitox), ${ }^{97}$ (2) by irradiation, ${ }^{98}$ (3) by inhibition of $\mathrm{T}_{\text {reg }}$ function (CTLA-4 antibodies [ie, ipilimumab]), ${ }^{99}$ (4) by blocking their migration to the tumor, ${ }^{100}$ and (5) by modifying key molecules in tumor microenvironment (ie, COX2 inhibitors, ${ }^{101}$ STAT3, ${ }^{17}$ extracellular cyclic AMP and adenosine) ${ }^{102}$ (Table $1^{17,93-102}$ and Figure 1).

A molecule of special interest for controlling $T_{\text {reg }}$ is ipilimumab. ${ }^{103-105}$ Ipilimumab (Yervoy ${ }^{\circledR}$, Bristol-Myers Squibb, New York, NY, USA) is a human immunoglobulin 1 monoclonal antibody able to bind to CTLA-4 receptors, thus blocking their interaction with protein B7. ${ }^{104}$ Several clinical trials have been conducted with this drug, particularly on melanoma and castration-resistant prostate cancer. ${ }^{104-109} \mathrm{~A}$ survival benefit has been obtained using a dose of $3 \mathrm{mg} / \mathrm{kg}$ endovenous every 3 weeks for four doses, ${ }^{104}$ with or without a melanoma vaccine polypeptide (glycoprotein 100).

An ipilimumab study by Hodi et al showed a median overall improvement in survival for stage III and IV melanoma patients from 6 to 10 months, and the drug's efficacy was unaffected by the presence of glycoprotein 100 vaccine. ${ }^{106}$ A study by Robert et al on ipilimumab and dacarbazine for 


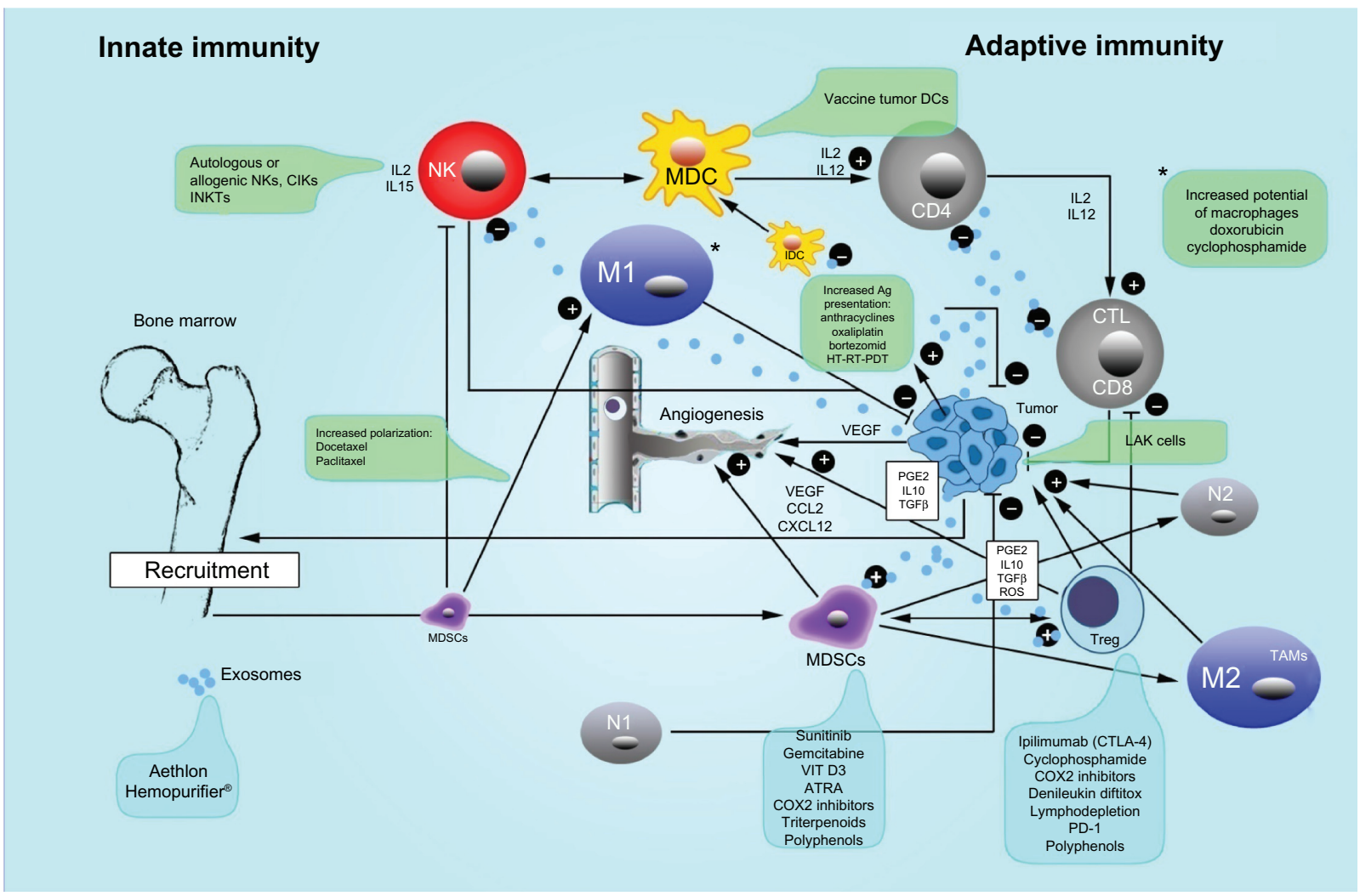

Figure I Innate and adaptive immunity in cancer and therapeutic interventions.

Notes: The crosstalk between innate immunity (natural killers [NK], type I macrophages [MI], type I neutrophils [NI], mature dendritic cells [MDC], immature dendritic cells [IMDC]) and adaptive immunity is illustrated. Antigen (Ag) presentation association to augmentative methods like hyperthermia (HT), radiotherapy (RT), photodynamic therapy (PDT), and chemotherapy (CT) is also illustrated. Further, the important immunosuppressive effects of regulatory $\mathrm{T}_{\text {cells }}\left(\mathrm{T}_{\text {reg }}\right.$ ), myeloid-derived suppressor cells (MDSC), type 2 macrophages (M2) (also called tumor-associated macrophages [TAM]) and the transformation of neutrophils from type I with antitumoral capacity versus type 2 (N2), which have angiogenic and pro-tumoral activity are shown. Exosomes, which carry immunosuppressive information, are also depicted. The various treatment methods used to control $\mathrm{T}_{\text {reg, }}$, myeloid-derived suppressor cells, and exosomes are in the blue frames, whereas the active treatments with several autologous and allogenic cells cytokine-induced killer [CIK] cells and invariant natural killers [INKT] are illustrated in the green frames. Lymphokine-activated killer [LAK] cells are depicted as "+," which indicates an augmentative effect, or "-," which indicates an inhibitory effect.

Abbreviations: ATRA, all-trans retinoic acid; CCL3, chemokine (C-C motif) ligand 3; CD, cluster of differentiation; COX2, cyclooxygenase-2; CTL, cytotoxic lymphocyte; CTLA-4, cytotoxic T-lymphocyte antigen 4; CXCLI2, chemokine (C-X-C motif) ligand I2; DCs, dendritic cells; IDC, immature dendritic cells; IL, interleukin; PD-I, programmed cell death protein I; PGE2, prostaglandin E2; ROS, reactive oxygen species; TGF- $\beta$, transforming growth factor beta; VEGF, vascular endothelial growth factor.

previously untreated metastatic melanoma, demonstrated an improvement in survival time, but increased side effects when compared with dacarbazine alone. ${ }^{107}$ Melanoma patients with brain metastases ${ }^{108}$ as well as cases of uveal melanoma ${ }^{109}$ have improved survival with Yervoy. Ipilimumab use has also been suggested for castration-resistant prostate cancer, ${ }^{110}$ as already mentioned, and lung tumors. ${ }^{111}$

However, important side effects from Yervoy have been reported, including tiredness, diarrhea, itching, rash, hemolytic anemia, infection, and death. ${ }^{112}$ The seriousness of some of these side effects has led Bakacs et al to consider ipilimumab a "catastrophe" and they have suggested a critical reassessment of immune checkpoint blockade methodology. ${ }^{113}$ It is our opinion that the effects of Yervoy on circulating $\mathrm{T}_{\text {reg }}$ are certain, but their action on $\mathrm{T}_{\text {regs }}$ in the tumor microenvironment is uncertain and even doubtful.
It has been suggested that monoclonal antibodies (mAbs) do not easily reach the targeted tumor mass. ${ }^{114}$ Reuben et al used another CTLA-4 inhibitor, ticilimumab (now called "tremelimumab"), in melanoma, and achieved results similar to those obtained with ipilimumab. ${ }^{115}$

Another class of immune checkpoint protein blockers is aimed to act as mAbs to programmed death receptor-1 (PD-1) ${ }^{116}$ and its ligand, PD-L1. These receptors are not only expressed on MDSC cells and $\mathrm{T}_{\text {reg }}{ }^{116}$ but are also overexpressed in a variety of human cancers including lung, ovarian, skin, colon, esophagus, renal, stomach, and breast. ${ }^{116,117}$ Another humanized mAb, BMS-936558 (immunoglobulin 4; BristolMyers Squibb), has generated interesting, albeit preliminary, results. ${ }^{18,119}$ The most striking of these is that melanoma and renal-cell cancers are the most responsive tumors - second only to those which immunohistochemical analysis shows are 
positive for PD-1 receptors on their surface. ${ }^{119-121}$ Side effects have been less severe than with Yervoy according to Tang and Heng, ${ }^{121}$ who assert that PD-L1 is selectively expressed on many tumors and within the tumor microenvironment when compared with CTLA-4. The most common side effects reported with use of the anti-PD-L1 antibody BMS936559 and anti-PD-1 antibodies (eg, BMS-936558) have been fatigue, rash, pruritus, arthralgia, and nausea (listed in order of appearance). ${ }^{121}$ As some authors have outlined, a combination of PD-1 and CTLA-4 antibodies seems possible and may be potentially synergistic; however, some caution must be exercised when using this combination in humans. ${ }^{122}$

The last group of immunosuppressive molecules released by tumors that we address here is exosomes. Exosomes are microparticles $30-100 \mu \mathrm{m}$ in size containing a variety of different molecules from signal peptides to mRNA, micro RNA, and lipids. They are either released into the extracellular fluid or may enter circulation, resulting in an increase in $\mathrm{T}_{\text {reg }}$ numbers, ${ }^{123}$ tumor progression, ${ }^{124}$ and tumor immune evasion. ${ }^{125}$ Recently, an interesting approach to removing these particles has been used that merits some attention. Using an ADAPT TM device (a "Hemopurifier ${ }^{\circledR}$ "; Aethlon Medical, San Diego, CA, USA), Marleau et al ${ }^{19}$ were able to remove exosomes containing human epidermal growth factor receptor 2 oncoproteins in patients with breast cancer overexpressing human epidermal growth factor receptor 2 receptors. This method is not altogether new, but the first attempts by Lentz ${ }^{126}$ used ultrapheresis in the treatment of solid tumors. This newer Hemopurifier approach uses the same cartridges used in standard dialysis units, thus does not require the purchase of a new device, making this a novel and easily incorporated technique.

\section{Conclusion}

Cancer is a complex system that learns to adapt to its environment, slowly recruiting its host for its own selfish growth and maintenance needs and to evade the immune system. Our rapidly developing understanding of the immune system and the tumor microenvironment is allowing researchers and clinicians to better target treatments against cancer. Understanding that the tumor microenvironment is hypoxic and in a state of chronic inflammation allows us to change variables to make the stroma less tumor promoting. Stimulation of the innate immune system may lead to shortterm benefits, to have a long- term benefic it must be followed by DC, IL-2/LAK or similar cytotoxic cell infusion. There are many exciting $\mathrm{mAbs}$ and drugs developed against various immune-related receptors such as Ipilimumab or PD-1, and for controlling $\mathrm{T}_{\mathrm{reg}}$ cells and MDSCs. Such immune system treatments hold a lot of promise. By harnessing our understanding of the immune system, we will be better able to work with this incredible system. By combining treatments aimed at both immunity and tumor microenvironment, it is our belief that a new benchmark in metastatic cancer therapy will be achieved.

\section{Disclosure}

The authors report no conflicts of interest in this work.

\section{References}

1. Croci DO, Salatino M. Tumor immune escape mechanisms that operate during metastasis. Curr Pharm Biotechnol. 2011;12(11): 1923-1936.

2. Mareel M, Constantino S. Ecosystems of invasion and metastasis in mammary morphogenesis and cancer. Int J Dev Biol. 2011; 55(7-9):671-684.

3. MacDonald N. Chronic inflammatory states: their relationship to cancer prognosis and symptoms. J R Coll Physicians Edinb. 2011; 41(3):246-253.

4. Germain RN. Tumor immunology. In: Benaceraff B, Unanue ER, editors. Textbook of Immunology. Baltimore, MD: Williams \& Wilkins; 1979:196-217.

5. Barrett AJ, Savani BN. Does chemotherapy modify the immune surveillance of hematological malignancies? Leukemia. 2009; 23(1):53-58.

6. Shurin MR, Naiditch H, Gutkin DW, Umansky V, Shurin GV. ChemoImmunoModulation: immune regulation by the antineoplastic chemotherapeutic agents. Curr Med Chem. 2012;19(12):1792-1803.

7. Wensveen FM, van Gisbergen KP, Eldering E. The fourth dimension in immunological space: how the struggle for nutrients selects highaffinity lymphocytes. Immunol Rev. 2012;249(1):84-103.

8. Voss MJ, Entschladen F. Tumor interactions with soluble factors and the nervous system. Cell Commun Signal. 2010;8:21.

9. Shiao SL, Ganesan AP, Rugo HS, Coussens LM. Immune microenvironments in solid tumors: new targets for therapy. Genes Dev. 2011;25(24):2559-2572.

10. Mellman I, Coukos G, Dranoff G. Cancer immunotherapy comes of age. Nature. 2011;480(7378):480-489.

11. Leibovici J, Itzhaki O, Huszar M, Sinai J. The tumor microenvironment: part 1. Immunotherapy. 2011;3(11):1367-1384.

12. Leibovici J, Itzhaki O, Huszar M, Sinai J. Targeting the tumor microenvironment by immunotherapy: part 2. Immunotherapy. 2011;3(11):1385-1408.

13. Martin F, Apetoh L, Ghiringhelli F. Role of myeloid-derived suppressor cells in tumor immunotherapy. Immunotherapy. 2012;4(1):43-57.

14. Hao NB, Lü MH, Fan YH, Cao YL, Zhang ZR, Yang SM. Macrophages in tumor microenvironments and the progression of tumors. Clin Dev Immunol. 2012;2012:948098.

15. Fridlender ZG, Sun J, Kim S, et al. Polarization of tumor-associated neutrophil phenotype by TGF-beta: "N1" versus "N2" TAN. Cancer Cell. 2009;16(3):183-194.

16. Bianchi G, Borgonovo G, Pistoia V, Raffaghello L. Immunosuppressive cells and tumour microenvironment: focus on mesenchymal stem cells and myeloid derived suppressor cells. Histol Histopathol. 2011; 26(7):941-951.

17. Byrne WL, Mills KH, Lederer JA, O’Sullivan GC. Targeting regulatory T cells in cancer. Cancer Res. 2011;71(22):6915-6920.

18. Munn DH. Blocking IDO activity to enhance anti-tumor immunity. Front Biosci (Elite Ed). 2012;4:734-745. 
19. Marleau AM, Chen CS, Joyce JA, Tullis RH. Exosome removal as a therapeutic adjuvant in cancer. $J$ Transl Med. 2012;10:134.

20. Ma Y, Conforti R, Aymeric L, et al. L. How to improve the immunogenicity of chemotherapy and radiotherapy. Cancer Metastasis Rev. 2011;30(1):71-82.

21. Rosental B, Appel MY, Yossef R, Hadad U, Brusilovsky M, Porgador A. The effect of chemotherapy/radiotherapy on cancerous pattern recognition by NK cells. Curr Med Chem. 2012;19(12): 1780-1791.

22. Baronzio G, Gramaglia A, Fiorentini G. Hyperthermia and immunity. A brief overview. In Vivo. 2006;20(6A):689-695.

23. Chang AE, Rosenberg SA. Overview of interleukin-2 as an immunotherapeutic agent. Semin Surg Oncol. 1989;5(6):385-390.

24. Rosenberg SA. The development of new immunotherapies for the treatment of cancer using interleukin-2. A review. Ann Surg. 1988; 208(2):121-135.

25. Tsung K, Norton JA. Lessons from Coley's Toxin. Surg Oncol. 2006; 15(1):25-28.

26. Wiemann B, Starnes CO. Coley's toxins, tumor necrosis factor and cancer research: a historical perspective. Pharmacol Ther. 1994; 64(3):529-564.

27. Rakoff-Nahoum S, Medzhitov R. Toll-like receptors and cancer. Nat Rev Cancer. 2009;9(1):57-63.

28. Lawson KA, Morris DG. Oncolytic virotherapy for renal cell carcinoma: a novel treatment paradigm? Expert Opin Biol Ther. 2012 12(7):891-903.

29. Patyar S, Joshi R, Byrav DS, Prakash A, Medhi B, Das BK. Bacteria in cancer therapy: a novel experimental strategy. J Biomed Sci. 2010; 17(1):21.

30. Restifo NP, Dudley ME, Rosenberg SA. Adoptive immunotherapy for cancer: harnessing the $\mathrm{T}$ cell response. Nat Rev Immunol. 2012;12(4):269-281.

31. Kiessling R, Klein E, Wigzell H. "Natural" killer cells in the mouse. Cytotoxic cells with specificity for mouse Moloney leukemia cells Specificity and distribution according to genotype. Eur J Immunol. 1975;5(2):112-117.

32. Caligiuri MA. Human natural killer cells. Blood. 2008;112(3): 461-469.

33. Biron CA, van den Elsen P, Tutt MM, Medveczky P, Kumar V, Terhorst $C$. Murine natural killer cells stimulated in vivo do not express the $\mathrm{T}$ cell receptor alpha, beta, gamma, T3 delta, or T3 epsilon genes. J Immunol. 1987;139(5):1704-1710.

34. Robertson MJ, Ritz J. Biology and clinical relevance of human natural killer cells. Blood. 1990;76(12):2421-2438.

35. Kärre K, Ljunggren HG, Piontek G, Kiessling R. Selective rejection of $\mathrm{H}$-2-deficient lymphoma variants suggests alternative immune defense strategy. Nature. 1986;319(6055):675-678.

36. Lanier LL. Natural killer cells: from no receptors to too many. Immunity. 1997;6(4):371-378.

37. Lanier LL. Missing self, NK cells, and the white album. J Immunol. 2005;174(11):6565.

38. Grimm EA, MazumderA, Zhang HZ, Rosenberg SA. Lymphokine-activated killer cell phenomenon. Lysis of natural killer-resistant fresh solid tumor cells by interleukin-2 activated autologous human peripheral blood lymphocytes. $J$ Exp Med. 1982;155(6):1823-1841.

39. Rosenberg SA, Lotze MT, Yang JC, et al. Prospective randomized trial of high-dose interleukin-2 alone or in conjunction with lymphokine-activated killer cells for the treatment of patients with advanced cancer. J Natl Cancer Inst. 1993;85(8):622-632.

40. Kammula US, Marincola FM. Cancer immunotherapy: is there real progress at last? BioDrugs. 1999;11(4):249-260.

41. Rosenberg SA. Immunotherapy of patients with advanced cancer using interleukin-2 alone or in combination with lymphokine activated killer cells. Important Adv Oncol. 1988:217-257.

42. Kimura H, Yamaguchi YA. A phase III randomized study of interleukin-2 lymphokine-activated killer cell immunotherapy combined with chemotherapy or radiotherapy after curative or noncurative resection of primary lung carcinoma. Cancer. 1997;80(1):42-49.
43. Sangiolo D. Cytokine induced killer cells as promising immunotherapy for solid tumors. J Cancer. 2011;2:363-368.

44. Weng DS, Zhou J, Zhou QM, et al. Minimally invasive treatment combined with cytokine-induced killer cells therapy lower the shortterm recurrence rates of hepatocellular carcinomas. $J$ Immunother. 2008;31(1):63-71.

45. Wu C, Jiang J, Shi L, Xu N. Prospective study of chemotherapy in combination with cytokine-induced killer cells in patients suffering from advanced non-small cell lung cancer. Anticancer Res. 2008;28(6B):3997-4002.

46. Shi L, Zhou Q, Wu J, et al. Efficacy of adjuvant immunotherapy with cytokine-induced killer cells in patients with locally advanced gastric cancer. Cancer Immunol Immunother. 2012;61(12):2251-2259.

47. Shubina IZh, Bliumenberg AG, Volkov SM, Demidov LV, Kiselevskiū MV. Adoptive immunotherapy of malignancies. Vestn Ross Akad Med Nauk. 2007;(11):9-15. Russian.

48. Morgan RA, Dudley ME, Wunderlich JR, et al. Cancer regression in patients after transfer of genetically engineered lymphocytes. Science. 2006;314(5796): 126-129

49. Donia M, Ellebaek E, Andersen MH, Straten P, Svane IM. Analysis of V $\delta 1$ $\mathrm{T}$ cells in clinical grade melanoma-infiltrating lymphocytes. Oncoimmunol. 2012;1(8):1297-1304.

50. Shi H, Liu L, Wang Z. Improving the efficacy and safety of engineered T cell therapy for cancer. Cancer Lett. 2013;328(2):191-197.

51. Keller R. Dendritic cells:their significance in health and disease. Immunol Lett. 2001;78:113-122.

52. Sallusto F, Nicolo C, De Maria R, Corinti S, Testi R. Ceramide inhibits antigen uptake and presentation by dendritic cells. J Exp Med. 1996;184(6):2411-2416.

53. Hsu FJ, Benike C, Fagnoni F, et al. Vaccination of patients with B-cell lymphoma using autologous antigen-pulsed dendritic cells. Nat Med. 1996;2(1):52-58.

54. Nestle FO, Alijagic S, Gilliet M, et al. Vaccination of melanoma patients with peptide- or tumor lysate-pulsed dendritic cells. Nat Med. 1998;4(3):328-332.

55. Rosenberg SA, Yang JC, Restifo NP. Cancer immunotherapy: moving beyond current vaccines. Nat Med. 2004;10(9):909-915.

56. Oshita C, Takikawa M, Kume A, et al. Dendritic cell-based vaccination in metastatic melanoma patients: phase II clinical trial. Oncol Rep. 2012;28(4):1131-1138.

57. Eggermont AM. Therapeutic vaccines in solid tumours: can they be harmful? Eur J Cancer. 2009;45(12):2087-2090.

58. Chrvala CA. The changing landscape of treatment options for metastatic castrate-resistant prostate cancer: challenges and solutions for physicians and patients. P T. 2012;37(8):453-463.

59. Plosker GL. Sipuleucel-T: in metastatic castration-resistant prostate cancer. Drugs. 2011;71(1):101-108.

60. Di Lorenzo G, Ferro M, Buonerba C. Sipuleucel-T (Provenge ${ }^{\circledR}$ ) for castration-resistant prostate cancer. BJU Int. 2012;110(2 Pt 2): E99-E104.

61. Cathelin D, Nicolas A, Bouchot A, Fraszczak J, Labbé J, Bonnotte B. Dendritic cell-tumor cell hybrids and immunotherapy: what's next? Cytotherapy. 2011;13(7):774-785.

62. Li H, Wang C, Yu J, et al. Dendritic cell-activated cytokine-induced killer cells enhance the anti-tumor effect of chemotherapy on non-small cell lung cancer in patients after surgery. Cytotherapy. 2009;11(8):1076-1083.

63. West EJ, Scott KJ, Jennings VA, Melcher AA. Immune activation by combination human lymphokine-activated killer and dendritic cell therapy. Br J Cancer. 2011;105(6):787-795.

64. Allen M, Louise Jones J. Jekyll and Hyde: the role of the microenvironment on the progression of cancer. J Pathol. 2011;223(2): $162-176$.

65. Khatami M. Unresolved inflammation: 'immune tsunami' or erosion of integrity in immune-privileged and immune-responsive tissues and acute and chronic inflammatory diseases or cancer. Expert Opin Biol Ther. 2011;11(11):1419-1432. 
66. Ben-Baruch A. Inflammation-associated immune suppression in cancer: the roles played by cytokines, chemokines and additional mediators. Semin Cancer Biol. 2006;16(1):38-52.

67. Kalinski P. Regulation of immune responses by prostaglandin E2. J Immunol. 2012;188(1):21-28.

68. Le Bitoux MA, Stamenkovic I. Tumor-host interactions: the role of inflammation. Histochem Cell Biol. 2008;130(6):1079-1090.

69. Harizi H, Gualde N. Pivotal role of PGE2 and IL-10 in the crossregulation of dendritic cell-derived inflammatory mediators. Cell $\mathrm{Mol}$ Immunol. 2006;3(4):271-277.

70. Sevko A, Umansky V. Myeloid-derived suppressor cells interact with tumors in terms of myelopoiesis, tumorigenesis and immunosuppression: thick as thieves. $J$ Cancer. 2013;4(1):3-11.

71. Karavitis J, Hix LM, Shi YH, Schultz RF, Khazaie K, Zhang M. Regulation of COX2 expression in mouse mammary tumor cells controls bone metastasis and PGE2-induction of regulatory $\mathrm{T}$ cell migration. PLoS One. 2012;7(9):e46342.

72. Sharma S, Yang SC, Zhu L, et al. Tumor cyclooxygenase-2/ prostaglandin E2-dependent promotion of FOXP3 expression and CD4+ CD25+ T regulatory cell activities in lung cancer. Cancer Res. 2005;65(12):5211-5220.

73. Obermajer N, Muthuswamy R, Lesnock J, Edwards RP, Kalinski P. Positive feedback between PGE2 and COX2 redirects the differentiation of human dendritic cells toward stable myeloid-derived suppressor cells. Blood. 2011;118(20):5498-5505.

74. Veltman JD, Lambers ME, van Nimwegen M, et al. COX-2 inhibition improves immunotherapy and is associated with decreased numbers of myeloid-derived suppressor cells in mesothelioma. Celecoxib influences MDSC function. BMC Cancer. 2010;10:464.

75. Desser L, Holomanova D, Zavadova E, Pavelka K, Mohr T, Herbacek I. Oral therapy with proteolytic enzymes decreases excessive TGF-beta levels in human blood. Cancer Chemother Pharmacol. 2001;47 Suppl:S10-S15.

76. Srivastava MK, Andersson Å, Zhu L, et al. Myeloid suppressor cells and immune modulation in lung cancer. Immunotherapy. 2012; 4(3):291-304

77. Pastuła A, Marcinkiewicz J. Myeloid-derived suppressor cells: a double-edged sword? Int J Exp Pathol. 2011;92(2):73-78.

78. Nagaraj S, Gabrilovich DI. Myeloid-derived suppressor cells in human cancer. Cancer J. 2010;16(4):348-353.

79. Greten TF, Manns MP, Korangy F. Myeloid derived suppressor cells in human diseases. Int Immunopharmacol. 2011;11(7):802-807.

80. Chalmin F, Mignot G, Ghiringhelli F. Myeloid-derived suppressor cells: a key player in cancer. Med Sci (Paris). 2010;26(6-7): 576-579.

81. Filipazzi P, Huber V, Rivoltini L. Phenotype, function and clinical implications of myeloid-derived suppressor cells in cancer patients. Cancer Immunol Immunother. 2012;61(2):255-263.

82. Kao J, Ko EC, Eisenstein S, et al. Targeting immune suppressing myeloid-derived suppressor cells in oncology. Crit Rev Oncol Hematol. 2011;77(1):12-19.

83. Naiditch H, Shurin MR, Shurin GV. Targeting myeloid regulatory cells in cancer by chemotherapeutic agents. Immunol Res. 2011; 50(2-3):276-285.

84. Djeu J, Wei S. Chemoimmunomodulation of MDSCs as a novel strategy for cancer therapy. Oncoimmunology. 2012;1(1):121-122.

85. Ghiringhelli F, Rebe C, Hichami A, Delmas D. Immunomodulation and anti-inflammatory roles of polyphenols as anticancer agents. Anticancer Agents Med Chem. 2012;12(8):852-873.

86. Ko JS, Zea AH, Rini BI, et al. Sunitinib mediates reversal of myeloid-derived suppressor cell accumulation in renal cell carcinoma patients. Clin Cancer Res. 2009;15(6):2148-2157.

87. Tongu M, Harashima N, Monma H, et al. Metronomic chemotherapy with low-dose cyclophosphamide plus gemcitabine can induce antitumor T cell immunity in vivo. Cancer Immunol Immunother. 2013; 62(2):383-391.
88. Lathers DM, Clark JI, Achille NJ, Young MR. Phase IB study of 25-hydroxyvitamin $\mathrm{D}(3)$ treatment to diminish suppressor cells in head and neck cancer patients. Hum Immunol. 2001;62(11):1282-1293.

89. Mirza N, Fishman M, Fricke I, et al. All-trans-retinoic acid improves differentiation of myeloid cells and immune response in cancer patients. Cancer Res. 2006;66(18):9299-9307.

90. Apetoh L, Végran F, Ladoire S, Ghiringhelli F. Restoration of antitumor immunity through selective inhibition of myeloid derived suppressor cells by anticancer therapies. Curr Mol Med. 2011;11(5):365-372.

91. van Cruijsen H, Hoekman K, Stam AG, et al. Defective differentiation of myeloid and plasmacytoid dendritic cells in advanced cancer patients is not normalized by tyrosine kinase inhibition of the vascular endothelial growth factor receptor. Clin Dev Immunol. 2007;2007: 17315

92. Ugel S, Delpozzo F, Desantis G, et al. Therapeutic targeting of myeloid-derived suppressor cells. Curr Opin Pharmacol. 2009; 9(4):470-481

93. Facciabene A, Motz GT, Coukos G. T-regulatory cells: key players in tumor immune escape and angiogenesis. Cancer Res. 2012;72(9): 2162-2171.

94. Wilke CM, Wu K, Zhao E, Wang G, Zou W. Prognostic significance of regulatory T cells in tumor. Int J Cancer. 2010;127(4):748-758.

95. Zou W. Regulatory T cells, tumour immunity and immunotherapy. Nat Rev Immunol. 2006;6(4):295-307.

96. Ghiringhelli F, Menard C, Puig PE, et al. Metronomic cyclophosphamide regimen electively depletes $\mathrm{CD} 4+\mathrm{CD} 25+$ regulatory $\mathrm{T}$ cells and restores $\mathrm{T}$ and $\mathrm{NK}$ effector functions in end stage cancer patients. Cancer Immunol Immunother. 2007;56(5):641-648.

97. Cools N, Ponsaerts P, Van Tendeloo VF, Berneman ZN. Regulatory T cells and human disease. Clin Dev Immunol. 2007;2007: 89195.

98. Muranski P, Boni A, Wrzesinski C, et al. Increased intensity lymphodepletion and adoptive immunotherapy - how far can we go? Nat Clin Pract Oncol. 2006;3(12):668-681.

99. Graziani G, Tentori L, Navarra P. Ipilimumab: a novel immunostimulatory monoclonal antibody for the treatment of cancer. Pharmacol Res. 2012;65(1):9-22.

100. Pere H, Tanchot C, Bayry J, et al. Comprehensive analysis of current approaches to inhibit regulatory T cells in cancer. Oncoimmunology. 2012;1(3):326-333.

101. Yaqub S, Henjum K, Mahic M, et al. Regulatory T cells in colorectal cancer patients suppress anti-tumor immune activity in a COX-2 dependent manner. Cancer Immunol Immunother. 2008;57(6): 813-821.

102. Mandapathil M, Szczepanski MJ, Szajnik M, et al. Adenosine and prostaglandin E2 cooperate in the suppression of immune responses mediated by adaptive regulatory T cells. J Biol Chem. 2010;285(36):27571-27580.

103. Dienstmann R, Markman B, Tabernero J. Application of monoclonal antibodies as cancer therapy in solid tumors. Curr Clin Pharmacol. 2012;7(2):137-145.

104. Lipson EJ, Drake CG. Ipilimumab: an anti-CTLA-4 antibody for metastatic melanoma. Clin Cancer Res. 2011;17(22):6958-6962.

105. Singh N, Madan RA, Gulley JL. Ipilimumab in prostate cancer. Expert Opin Biol Ther. 2013;13(2):303-313.

106. Hodi FS, O'Day SJ, McDermott DF, et al. Improved survival with ipilimumab in patients with metastatic melanoma. $N$ Engl $\mathrm{J} \mathrm{Med}$. 2010;363(8):711-723.

107. Robert C, Thomas L, Bondarenko I, et al. Ipilimumab plus dacarbazine for previously untreated metastatic melanoma. $N$ Engl J Med. 2011; 364(26):2517-2526.

108. Margolin K. Ipilimumab in a Phase II trial of melanoma patients with brain metastases. Oncoimmunology. 2012;1(7):1197-1199.

109. Khattak MA, Fisher R, Hughes P, Gore M, Larkin J. Ipilimumab activity in advanced uveal melanoma. Melanoma Res. 2013;23(1):79-81.

110. Gerritsen WR. The evolving role of immunotherapy in prostate cancer. Ann Oncol. 2012;23 Suppl 8:viii22-viii27. 
111. Reck M, Bondarenko I, Luft A, et al. Ipilimumab in combination with paclitaxel and carboplatin as first-line therapy in extensive-diseasesmall-cell lung cancer: results from a randomized, double-blind, multicenter phase 2 trial. Ann Oncol. 2013;24(1):75-83.

112. Fellner C. Ipilimumab (Yervoy) Ipilimumab (yervoy) prolongs survival in advanced melanoma: serious side effects and a hefty price tag may limit its use. P T. 2012;37(9):503-511.

113. Bakacs T, Mehrishi JN, Moss RW. Ipilimumab (Yervoy) and the TGN1412 catastrophe. Immunobiology. 2012;217(6):583-589.

114. Thurber GM, Schmidt MM, Wittrup KD. Factors determining antibody distribution in tumors. Trends Pharmacol Sci. 2008;29(2):57-61.

115. Reuben JM, Lee BN, Li C, et al. Biologic and immunomodulatory events after CTLA-4 blockade with ticilimumab in patients with advanced malignant melanoma. Cancer. 2006;106(11):2437-2444.

116. Topalian SL, Drake CG, Pardoll DM. Targeting the PD-1/ B7-H1(PD-L1) pathway to activate anti-tumor immunity. Curr Opin Immunol. 2012;24(2):207-212.

117. Okazaki T, Honjo T. PD-1 and PD-1 ligands: from discovery to clinical application. Int Immunol. 2007;19(7):813-824.

118. Zitvogel L, Kroemer G. Targeting PD-1/PD-L1 interactions for cancer immunotherapy. Oncoimmunology. 2012;1(8):1223-1225.

119. Ménétrier-Caux C, Curiel T, Faget J, Manuel M, Caux C, Zou W. Targeting regulatory T cells. Target Oncol. 2012;7(1):15-28.
120. Topalian SL, Hodi FS, Brahmer JR, et al. Safety, activity, and immune correlates of anti-PD-1 antibody in cancer. $N$ Engl J Med. 2012; 366(26):2443-2454.

121. Tang PA, Heng DY. Programmed Death 1 Pathway inhibition in Metastatic Renal Cell Cancer and Prostate Cancer. Curr Oncol Rep. 2013;15(2):98-104.

122. Curran MA, Montalvo W, Yagita H, Allison JP. PD-1 and CTLA-4 combination blockade expands infiltrating $\mathrm{T}$ cells and reduces regulatory T and myeloid cells within B16 melanoma tumors. Proc Natl Acad Sci USA. 2010;107(9):4275-4280.

123. Zhang HG, Grizzle WE. Exosomes and cancer: a newly described pathway of immune suppression. Clin Cancer Res. 2011;17(5): 959-964.

124. Camussi G, Deregibus MC, Bruno S, Grange C, Fonsato V, Tetta C. Exosome/microvesicle-mediated epigenetic reprogramming of cells Am J Cancer Res. 2011;1(1):98-110.

125. Iero M, Valenti R, Huber V, et al. Tumour-released exosomes and their implications in cancer immunity. Cell Death Differ. 2008; 15(1):80-88.

126. Lentz MR. Continuous whole blood UltraPheresis procedure in patients with metastatic cancer. J Biol Response Mod. 1989;8(5):511-527.

\section{Publish your work in this journal}

ImmunoTargets and Therapy is an international, peer-reviewed open access journa focusing on the immunological basis of diseases, potential targets for immune based therapy and treatment protocols employed to improve patient management. Basic immunology and physiology of the immune system in health, and disease will be also covered. In addition, the journal will focus on the impact of manage-

\section{Dovepress}

ment programs and new therapeutic agents and protocols on patient perspectives such as quality of life, adherence and satisfaction. The manuscript management system is completely online and includes a very quick and fair peer-review system, which is all easy to use. Visit http://www.dovepress.com/testimonials.php to read real quotes from published authors.

Submit your manuscript here: http://www.dovepress.com/immunotargets-and-therapy-journal 